\title{
Social Science: Caring for Children in Young Family Due to Pregnant Outside Marriage
}

\author{
M. Khoirul Hadi al Asy ari ${ }^{1, *}$, Muhammad Rahman ${ }^{2} * * *$ \\ ${ }^{1}$ Santri Ma'had Aly IAIN Jember and Lecturer Staff of the IAIN Jember Faculty of Sharia and Nurture the IMC Study Community IAIN Jember, \\ ${ }^{2}$ Islamic Economics Law Study Program Student IAIN Jember \\ Email: hadiariiainjember@iain-jember.ac.id*,mr339514@gmail.com**
}

\begin{abstract}
Writing this paper aims to determine the function and influence of the family on a child, young families as a result of marride will be accidentally influenced by child care, where ideal care will be seen at the time of loyalty, attention and attention of parents to children in order to grow into a better generation. However, being too young to get married will hamper the knowledge of young couples about ideal parenting. The purpose of this study is to describe the knowledge of parenting in young families, to describe the problems of childcare and to describe the forms of care for young families as a result of accidental marriage. This research was conducted with a qualitative approach. The results of this study are the lack of knowledge about ideal parenting, so that parenting has changed the function of young families into their grandmothers or sisters. Care for young families with problems is seen from three factors: parenting, actors playing and the obstacles faced while having children. There are four forms of parenting namely democratic parenting, authoritarian parenting, permissive parenting and parenting style. Different parents will apply different parenting styles as well. However, the mayor of a young family uses democratic nurturing because they prioritize the importance of children but remain under the supervision of parents, parents are more rational, realistic, open, and able to communicate well with children. Democratic parenting style is mainly used to produce characteristics of children who are independent, obedient, honest, good communication and cooperative with others. There are several important questions in this paper, first. What is the ideal childcare method. Second. What is the impact of parents' lack of attention on a child. Third. How is the solution to bring together families who are broken home. Interview, data collection, and documentation methods are used in this paper to obtain maximum and concrete results. So that this paper can be used as a solution for families who are experiencing problems both internally and externally.
\end{abstract}

Keywords: Premarital Pregnancy, Young Families, Children, Family Problems

\section{INTRODUCTION}

Humans in the process of development to get offspring need a partner in accordance with their desires and religion. Marriage is a way to realize a happy and eternal family or household based on the Godhead. The family is the source of the first place and a fundamental basis for the development and growth of children, which includes parents, relatives and close relatives. From contiguity the first child is with family. The family is a social group that is usually centered on a batih family that is a family consisting of fathers, mothers and children who are not married or separated. The family has an important role for the development and education of a child, which is responsible for educating, nurturing and guiding their children to reach certain stages so that eventually a child is ready in social life.

According to Edwards, discussing childcare is the interaction of children and parents to educate, guide, and discipline and protect children to reach maturity in accordance with the norms that exist in society. The basic characteristics of an ideal family basically revolve around logical, ethical and aesthetic aspects. Being logical means that parents can prove what is right and what is wrong. And it seems that this is not too difficult to do, but it depends on how it is applied by parents in relation to children. Ethical attitude means being based on certain standards and getting strong pressure from other things, so that it is not reckless and aesthetic behavior means that parents live well without causing discomfort from the other party. Whether or not parenting is applied depends on the figure of the parents themselves. Every parent who will provide different forms of care according to the background of parenting so that will produce a variety of different care from different parents. Any difference in parenting depends on behavior.

Parental behavior is manifested through educating parents' ways of educating their children to become better. The way parents educate their children is called nurturing because a child tends to use certain methods that are considered best for him. This is where it has several differences in parenting. On one hand parents must be able to determine the right way of care in considering the needs and situations of children and on the other hand as parents also have the desire and become a desire of parents to shape the child into someone who is aspired to be certainly better than their parents. Based on empirical assumptions, there are difficulties for parents in implementing childcare. The difficulty is seen from the way parents raise, educate, give love, and their responsibilities towards children. 
The majority of these factors are experienced by young families who are pregnant out of wedlock. This is caused by the lack of knowledge of young families related to childcare. Today's adolescent association is increasingly unhealthy, with the rise of entertainment that tempts the unstable teenage soul. In this unstable period, teenagers need information, including things that are very sensitive such as sexuality. From promiscuity to trigger marriages that form young families, who are forced by conditions that occur unconsciously all because of lust and emotions of young age, so that the age of marriage is too young resulting in conflict in the family due to lack of awareness to be responsible for married life for husband and wife who will build a new family.

Until the impact, many young couples forget their responsibilities as parents. This greatly affects the pattern of child care for these young families. Viewed from the economic side of the husband has not been able to make a living meet family needs. From the husband's side always involves the figure of parents, in-laws or relatives, as well as other family (relatives). This is psychologically very burdensome and prone to result in misunderstanding both husband and wife and extended family and the most victims are the children in the family. When a child is at an age that requires full nutritional intake, but is not available properly due to limitations. The impact of course the development of brain cells and soul undergo limitations which certainly affects the future of the future.

\section{Childcare}

Child rearing is the treatment of parents in their interactions with children which includes parents showing power and ways to pay attention to children's desires. Power or the method used by parents tends to lead to parenting that is applied. (Hidayah R., 2009) Parenting of children is also the interaction of children with parents to educate, guide and discipline and protect children to achieve maturity in accordance with existing norms in Public. In Prasetyo's opinion there are 4 forms of parenting for parents:

a. Democratic Parenting: A way of parenting that prioritizes the interests of children, but does not hesitate to control them. Parents use this parenting to be rational, always basing their actions on ratios or thoughts.

b. Authoritarian parenting: this Parenting tends to set standards that absolutely must be followed, usually coupled with threat threats. Based on this type, parents are more likely to force, rule, punish if the child does not want to do what is said by parents, then this type of parent does not hesitate to punish the child.

c. Permissive parenting: this Parenting provides very loose supervision. Will give the child an opportunity to do something without enough supervision from him so that it results in violating existing norms.
They tend not to reprimand or warn the child if the child is in danger more likely to let.

d. Parenting Care: Parents of this type generally give very little time and money to their children. So that their time is more used for their own personal needs, such as work, and also sometimes the cost is saved for their children.

\section{Family Concepts}

The family in this concept is an inseparable part of life. The family becomes the first place someone starts his life. In the family forming a very close relationship between father, mother, and child. (Sediyaningsih, S. 2013)

The relationship occurs where family members interact and protect each other. This interaction makes a familiar relationship within the family, under normal circumstances, the first environment associated with children is their parents, siblings and possibly close relatives who live together.

According to Suhendi, the function of family in life consists of: first, Biological Function, closely related to the sexual needs of husband and wife. Second, the socialization function of a child, refers to the role of the family in shaping the child's personality by introducing patterns of behavior, attitudes, beliefs, ideals and values adopted by the community and in accordance with applicable norms. Third, the function of affection, the need for affection or love. Fourth, the Educational Function, the family is the first teacher in educating humans. Fifth, Religious Function, the function of religion in the family is one indicator of a prosperous family. Sixth, Protective Function, a comfortable place for its members. Seventh, the Creative Function, aims to provide a fresh and happy atmosphere in the family. Eighth, Economic Function, Demos notes that "The family is the primary unit that produces economic needs. For some families, the situation is like a factory, each working in accordance with their duties. Ninth, Function of Unity of Status, in a family a person receives a series of status based on age, birth order, and so on. Status or position is a rank or position of someone in a group or group position in relation to other groups.

\section{Unwed pregnancy}

Pregnant out of wedlock is all intercourse between men and women that is done out of wedlock which results in a woman getting pregnant before entering into a marriage contract. The occurrence of an unmarried pregnancy event, other than because of promiscuity, is also due to weak faith in each party. As for a number of factors that cause sexual relations outside of marriage according to Sarlito, are first, the number of stimuli that are pornographic in the form of films, reading material, or in the form of peer conversations, which are a result of the second globalization stream, the availability of opportunities for sexual acts. From social conditions also 
allows for the occurrence of pregnancy outside marriage which tolerates promiscuity between men and women. Customs that once looked at taboo related to free relations between men and women, are now becoming increasingly loose. On the other hand, relating to the rule of criminal law does not include sexual relations outside of legal marriage conducted by men and women on the basis of like and like. As a result, as members of the community, they are not afraid to have sex outside of marriage because there is no positive law that will ensnare it.

\section{Sociological approach}

From this the researcher analyzes by using the Social Action theory developed by Max Weber. The social action referred to here is an individual action which as long as the action has a subjective meaning or meaning for itself and is directed towards the actions of others so that the action results in something positive for him. Weber can definitively formulate sociology as a science that seeks to interpret and understand social interpretations as well as between social relations to arrive at causal explanations. How can you understand the motives and actions of the informant? Weber suggests that there are two ways: first, through seriousness and second, by trying to remember and dive into the experiences of informants. A Weber also explained about rationality which is the basic concept used in classifying the types of social action. The main difference given is between rational and non-rational actions. In short, rational action deals with conscious consideration and choice that the action is expressed. Some types of social action that consists of: first, Instrumental Rational Actions: This highest rational action includes conscious consideration and choice related to the goals and tools used to achieve them. Second, Value-Oriented Rational Actions: Valueoriented rational traits are important that tools are only conscious objects of judgment and calculation, whereas goals already exist in relation to individual values that are absolute or final values for them. Third, Affective Actions: Affective actions or emotional actions are characterized by the dominance of feelings without intellectual reflection or conscious feeling. Fourth, Traditional Action: This action is a habit for him, where the goals and methods are not thought of, but the actor can explain the reason for doing that refers to tradition. Haningrum, R. D. (2013). Resiliensi pada remaja yang hamil di luar nikah

\section{MATERIALS AND METHODS}

This research uses a qualitative research method. Qualitative research methods which are defined by Social Sciences research methods that collect and analyze data in the form of words (oral and written) and human actions and researchers do not try to calculate and quantify the qualitative data that has been obtained and thus do not analyze the numbers .

This study provides an overview of social reality, therefore this research is descriptive. Descriptive research is research that describes a phenomenon or social reality relating to the problem and unit under study. The use of this method provides the opportunity for researchers to collect data sourced from interviews, field notes, photographs, personal documents, notes and memos to illustrate the subject of research.

\section{RESULTS AND DISCUSSION}

\section{Knowledge of Young Families About Childcare}

Knowledge is information that is known by someone both obtained from relationships with the environment, reactions, communication and thoughts so as to produce something that grows and is embedded in one's mind. In this study, researchers explore the knowledge of young families related to childcare. A marriage by a young family is bad for them, where the young men and women are not emotionally mature, knowledgeable, economically and dominantly spoiled, and the most victims are children. Where the figure of parents will be constrained by how to ideally care for children.

The more ideal way of parenting is a method that is carried out in caring for, maintaining and educating children continuously from time to time as a manifestation of parents' sense of responsibility towards children. In addition, parents also have to know completely about the characteristics possessed by children through interaction because the role of parents is so great in helping children to become good personalities in the future. From the ideal childcare can also be seen from the actors who play a role in the care. If a child is cared for by his own parents then the child will get an ideal pattern of care compared to the child entrusted or cared for by others. On the other hand, it must be seen from the way parents protect, protect, educate, instill values and norms and carry out the affective function. This is the most dominant way of parenting as the first and foremost teacher of children. Sources of knowledge and abilities are very helpful for young families in providing care patterns for children, especially parents. In addition to parents, electronic media such as the internet are also very helpful in contributing to providing knowledge about how to care for children. The source of knowledge is not only obtained at formal education levels but also found through the family, the media and the surrounding environment, in the sense that care is not focused on just one source, but many other references that explain how to care for children well, so that constraints obstacles faced by young families can be minimized. 


\section{Problems With Childcare For Young Families Due To Pregnancy Outside Marriage}

Problematics is the gap between expectations and reality that creates endless problems. This problem is easy to occur due to low and lack of knowledge, ideological influence, immature thinking and external factors that will affect a person's condition. In this study, it was found that there are three problems of childcare experienced by young families including: first, how to care for children, second, actors who play a role in care, third, economic conditions.

In this indicator, the way childcare tends to be a problem for young families who are pregnant out of wedlock. Many young family couples are adrift about how to care for their children so they are not abandoned. Based on the observations of researchers, children are more often raised by their grandmothers than their biological parents. Even though the child is cared for by a young family, it is only limited to carrying and playing with the child compared to the figure of his grandmother. They still need to learn and learn more about how to care for the child so that the responsibility of parents as the first socialization agent that can be realized. While the dominant actors in childcare are parents (grandmothers), although they are inseparable from the interference of young families and siblings. Having a child will change many things in a previous life, in the end as a parent it is demanded to be ready to be a parent who must be able to provide life for their future well as a child's right. Therefore, if the parents are still too young, usually in educating children will be transferred to parents (grandmothers) due to the inability of young families in terms of knowledge and experience and result in them living together with their parents, another thing is also caused by the inability to prepare post-marriage facilities and infrastructure. In addition to the way of nurturing and the actors involved, in economic conditions is one of the problems of caring for children in young families.

This is due to simple work with little income which results in low education. The work referred to here is a type of business that is done to be able to make money, where parents usually have to try to find work for the sake of children and meet family needs. Especially for the figure of the father as head of the household who has a great responsibility for his wife and children. Especially now where economic conditions are uncertain, to meet the needs of family life both husband and wife try to find work in order to get money to meet the needs of everyday life and the demands of children in the form of education.

The type of work or business carried out by young families varies greatly, from the data obtained consisting of workshops, mini market employee traders, building servants and housewives. The diversity of work and social status of young families has one goal in common: meeting the needs of children and meeting the needs of everyday life. The work occupied by the young family will not be sufficient for good nutrition for their children because the income received is not fixed so that the child becomes the economic victim of the parents who are lacking in economic terms. Of the many divorce cases, often too young marriages can also lead to an increase in divorce cases due to lack of awareness and maturity to be responsible in married life for husband and wife and uncontrolled emotions both. But in fact, there are many married couples who marry at a young age. One contributing factor is pregnancy out of wedlock due to uncontrolled promiscuity. Free promiscuity is a trigger for early marriages that are full of compulsion over the conditions that occur so that adolescents must get married and form a young family that has not been conceptualized. The lack of knowledge in family management that is supported by insight into thinking and not yet ripe mentally will always be swayed in doubt and ambiguity each will step or decide on something even the most trivial. Moreover, most young marriages are forced so that economically the husband is sometimes not able to make a living to meet family needs and the needs of children.

This is psychologically very burdensome and prone to result in misunderstanding both husband and wife and children as victims of the misunderstanding, so it is found that the husband leaves the child and wife without news that results. Another obstacle faced by parents is the less established economic aspect. This is caused by the low education of parents so that they find it difficult to compete in the workforce and invest in work matters. Most of them did not graduate from high school, lack of skills and lack of work experience. Plus the increasingly tense situation worsened by the wife who holds the status as a single parent. Single parent families can be caused by divorce, death, foster parents and parents who are separated (not divorced) and something that results in separation. Mothers will play a dual role in breadwinners and child caregivers. So, the impact of a single parent's family life on a child's personality is very significant and independent of the child.

\section{Forms of Care for Children in Young Families Due to Pregnancy Outside Marriage}

Children are a valuable treasure for every parent. Every parent would want to have children who are smart, healthy, virtuous, and of good character. We often hear the expression that a child is a reflection of the personality of their parents who are more public figures. This is true, because from the womb and being born and then growing up, a child is totally dependent on his parents or those who care for him to raise him. So that the character of a parent or caregiver will have a major impact on the physical growth and mental and mental development of a child. Each parent will provide different forms of care according to the educational background, social and cultural life of the parents and parental care itself so that it will produce different kinds 
of care from parents who also have different caregiving methods.

From the results of the study, it was found that 4 out of 6 informants would apply a form of democratic nurture to their children from an early age because that was more positive. This means that democratic nurturing is the best way applied by parents in shaping the character and personality of children, because this democratic nurture is characterized by parents being rational, respecting and understanding the child's situation with its strengths and weaknesses so that children can become mature, outgoing, and able to adjust to good and right. Democratic care will produce children who are independent, able to control and maintain themselves, able to interact well, flexible, open and cooperative towards other people who are different from their personalities. Parents are very meritorious in the lives of children, for example a mother with great difficulty conceiving us for 9 months, nurturing, sacrificing time, giving love to the child she raised. Meanwhile, fathers, who struggle to sweat, work hard to support their wives and children, work tirelessly hoping their children and wives get a decent and comfortable life in a family. So what do parents really hope for their children?

One of them is to be a child who can be proud of both parents. There is no single parent who wants to see their children living in hardship and destitution. All efforts will be made by parents so that their children will be able to live prosperously, and parents will be happier when the welfare achieved by children can boast them in the future. Regardless of whether a child will become an official, a company leader, a successful businessman or just an ordinary person, as long as he lives well and meets his needs and future and is able to be a helper to the community, of course it is very proud of his parents who as the driver of his success. This means that many big hopes that parents lay on their children later to be picked in the future.

However, this hope will not be realized by itself if parents do not apply proper care for their children starting early. Every parent has the right to choose what form of care he thinks is most appropriate for his child and what education is appropriate for him. Democratic care is the most appropriate care for children's development. Democratic care adopted by parents is one of the factors in the formation of independence in children. Democratic nurture is a way of nurturing whereby children may express their own opinions, discuss their views with parents, determine and make decisions. However, parents still carry out supervision and guidance in terms of making the final decision so as not to slip in the future. In this case, the role of parents in care is more in the form of guidance, dialogue, and giving reasons for the rules in the process of forming a more ideal independence.

\section{CONCLUSIONS}

The low knowledge of young families due to pregnancy out of wedlock separates them from implementing the ideal and appropriate parenting patterns for the children themselves. Young families tend to get sources of information from parents and the media only when they hold the status of a young family, the rest is not focused. So that with a relatively short time, it becomes an inhibiting factor for young families to get the ideal parenting patterns and transfer the affective function of parents to others who are more experienced than them, so that children are vulnerable to becoming victims of family violence. With the lack of knowledge and constraints parents apply parenting that will affect the personality of the child later.

The problem of parenting that is often faced by young families is that the age of marriage is too young resulting in a lack of awareness to be responsible in married life for husband and wife to make a harmonious family. There are 3 problems found, namely childcare, actors who play a role in parenting and the most important economic conditions. Democratic nurturing is the best way applied by parents in shaping the character and personality of children, because this form of democratic nurture is characterized by parents being rational, respecting and understanding the child's situation with its strengths and weaknesses so that children can become mature, outgoing, and able to adjust to better and more ideal. Through democratic nurture will shape the child's personality that is characterized and always upholds the values of national civilization and the truth of moral ethics.

\section{REFERENCES}

Afrizal. (2014). Metode Penelitian Kualitatif. Jakarta: PT. Raja Grafindo Persada.

Agus, S. (2013). Pola Pengasuhan terhadap Anak Pada Keluarga Orang Tua Tunggal (Studi pada 4 orang tua tunggal di Bandar Lampung). Lampung: Skripsi Jurusan Sosiologi FISIP Universitas Lampung.

Basri, H. (1996). Remaja Berkualitas Problematika dan Solusinya. Yogyakarta: Pustaka Pelajar.

Edwards, D. (2006). Ketika Anak Sulit Diatur. Jakarta: Salemba Medika.

Goode, W. (2007). Sosiologi Keluarga. Jakarta: Bumi Aksara.

Gunarsa, G. (2000). Psikologi Praktis: Anak Remaja dan Keluarga. Jakarta: Gunung Mulia.

Horton, P. B., and Hunt, C. L. (1996). Pengantar Sosiologi. Jakarta: Erlangga.

Husodo, T. (1987). Seksualitas Dalam Mengenal Dunia Remaja. Bandung: Eresco.

Ismayani. (2006). Dampak Sosial kehamilan di Luar Nikah (Studi di Kecamatan Lubuk Begalung Kota Padang). Padang: Skripsi Jurusan Sosiologi FISIP Universitas Andalas Padang. 
Memed, H. (2002). Akad Nikah Wanita Hamil dan Anaknya. Jakarta: Gema Insane.

Moleong, L. J. (2010). Metodologi Penelitian Kualitatif. Bandung: Remaja Rosdakarya.

Prasetyo, T. G. (2003). Pola Pengasuhan Anak. Jakarta: Aksara Baru.

Santrok, J. W. (2003). Edisi Keenam Adolesce: Perkembangan Remaja. Jakarta: Erlangga

Schott, J. (2012). Teori Sosial: Masalah-Masalah Pokok dalam Sosiologi. Yogyakarta: Pustaka Belajar.
Soekanto, S. (2004). Sosiologi Keluarga. Jakarta: Rineka Cipta.

Hidayah, R. (2009). Psikologi pengasuhan anak. UIN-Maliki Press

Haningrum, R. D. (2013). Resiliensi pada remaja yang hamil di luar nikah

Sediyaningsih, S. (2013). Analisis model komunikasi pembentukan konsep keluarga sejahtera di Indonesia (Studi terhadap sosialisasi program BKKBN Kota Depok dan Kota Bogor). Jurnal Organisasi dan Manajemen, 9(2), 145-161. 